\title{
QUEST FOR UTOPIAN IMPULSE IN TWENTIETH-CENTURY DYSTOPIAN NARRATIVE: P. D. JAMES'S CRITICAL DYSTOPIA, THE CHILDREN OF MEN ${ }^{1}$
}

\begin{abstract}
Dystopian narrative has gained enormous worldwide recognition and popularity with an upsurge in the number of literary dystopias and dystopian films. Dystopia presents alternative world scenarios, which project a relatively worse dystopian social order than the current experienced one, thereby functioning as a cautionary tale. Twentieth century witnessed the emergence and gradual rise of dystopia in the aftermath of the socio-political conjuncture and led dystopia to be generally interpreted as pessimistic. However, twentieth-century dystopian fiction is not completely pessimistic since it signifies hope through open-ended narratives, especially in the critical dystopias of the century. The experiential journey motif, which facilitates potential transformation in the character's stance on the dynamics of the projected system, plays a significant role in eliciting the utopian impulse. The aim of this article is therefore to discuss the possibility of hope in twentieth-century dystopian fiction through a comprehensive analysis of P. D. James's critical dystopia, The Children of Men (1992), which has not achieved critical and scholarly acclaim it deserves, probably due to the success of Alfonso Cuaron's film, Children of Men (2006).
\end{abstract}

Keywords: critical dystopia, hope, P. D. James, journey, utopian impulse

\section{YÜZYIL DISTOPIK ANLATISINDA ÜTOPIK DÜRTÜ ARAYIŞI: P. D. JAMES'IN ÜMITVAR DISTOPYASI, THE CHILDREN OF MEN ${ }^{3}$ ÖZ}

Distopik romanlardaki ve filmlerdeki artış, distopik anlatının dünya çapında tanınırlık kazanmasına büyük ölçüde katkıda bulunmuştur. Distopya, deneyimlenen toplumsal düzene kıyasla daha kötü bir toplum düzenini yansıtan alternatif dünya senaryolarını sunmaktadır. $\mathrm{Bu}$ bağlamda distopyanın uyarıcı, ikaz edici bir boyutu da bulunmaktadır. 20. yüzyll, distopyanın sosyo-politik konjonktür sonrası ortaya çıkışına ve kademeli gelişimine tanıklık etmiştir. Bu da distopyanın karamsar bir tür olarak algılanmasına yol açmıştır. Ancak,

\footnotetext{
${ }^{1}$ This article has been produced from my ongoing doctoral dissertation.

${ }^{2}$ Research Assistant, Hacettepe University, Department of English Language and Literature, atasoy.emrah@hacettepe.edu.tr, ORCID: 0000-0002-5008-2636

${ }^{3} \mathrm{Bu}$ makale devam eden doktora tezinden üretilmiştir.
} 


\section{Emrah ATASOY}

20. yüzyıl distopik anlatısı tamamıyla karamsar değildir çünkü bu yüzyılda yazılan romanların, özellikle de eleştirel distopyaların açık uçlu yapısı umudu barındırmaktadır. Eserdeki karakterin, tasarlanan sistemin dinamiklerine olan tutumunda olası bir değişimi mümkün kllan ve tecrübeye dayanan seyahat motifi, ütopik dürtünün ortaya çıkarılmasında önemli bir rol oynamaktadır. Bu anlamda bu makalenin amacl, muhtemelen Alfonso Cuaron'un Children of Men (Son Umut, 2006) başlıklı filminin başarısı yüzünden şu ana kadar hak ettiği değeri görmeyen P. D. James'in ümitvar ${ }^{4}$ distopyası, The Children of Men (1992)'in kapsamlı analizi üzerinden, 20. yüzyıl distopik anlatısında umudun olasılığını tartışmaktır.

Anahtar Kelimeler: eleştirel distopya, umut, P. D. James, seyahat, ütopik dürtü

\section{Introduction: Insight into Dystopia \& Critical Dystopia in the Twentieth Century}

Utopian narrative fell from grace at the outset of the twentieth century. Dystopian narrative accordingly superseded the popularity of eutopia or positive utopia, which Prof. Lyman Tower Sargent, one of the most distinguished scholars in the field of utopian studies, describes as "a non-existent society described in considerable detail and normally located in time and space that the author intended a contemporaneous reader to view as considerably better than the society in which the reader lived" ("The Three Faces," 1994: 9). This paradigmatic shift from utopia to dystopia resulted from the social, political, historical and cultural events, most of which were relatively catastrophic and pernicious, in the course of the century.

This radical shift from the utopian propensity to the dystopian tendency in this century occurred under the enormous influence of such events, incidents and developments as the rise of totalitarian and fascist regimes in the countries such as Germany and Spain, the First and Second World Wars, the gradual advancement of technology, and social movements. When the promoted utopian politics failed, the utopian ideals and ensuing belief in these notions were drastically shaken since these monolithic regimes turned Europe into an uninhabitable and unbearable place and diminished the likelihood of

\footnotetext{
${ }^{4}$ Critical dystopia has not been dealt with in Turkish literature or has not been translated into Turkish language; therefore, I suggest "ümitvar distopya (or eleştirel distopya, umut içeren distopya, içinde umut barındıran distopya,)" as the translation of the concept of "critical dystopia."
} 
a more ideal world. Moreover, Prof. Tom Moylan also elucidates the preponderance of literary dystopias in this century as: "A hundred years of exploitation, repression, state violence, war, genocide, disease, famine, ecocide, depression, [and] debt ... provided more than enough fertile ground for this fictive underside of the utopian imagination" (2000: xi). Consequently, the feasibility of utopian alternatives was heavily challenged by the projections of dystopian narrative.

What people actually experienced in this century in line with utopia, which "expresses and explores what is desired," did not augur well for the realization of the utopian desire (Levitas, 1990: 191). Subsequently, literary illustrations began to picture how these utopian ideals might fail, which functions as cautionary. This skepticism pervades the literary ambiance of the time through production of dystopian novels, which highlight worse societies, and imply a lack of hope for a more ideal future. A critical outlook on literary utopias is therefore portrayed through the representation of comparatively nightmarish societies. These novel depictions "cast a haunting shadow over the idyllic landscape of utopia," and present an anti-utopian landscape (Bammer, 1991: 19). As a result, dystopian genre prevails the literary aura of the time rather than the utopian narrative; however, this does not mean that people gave up dreaming about better worlds and societies.

John Stuart Mill (1806 - 1873), the English economist and philosopher is generally credited with the word, dystopia, which Mill used in a speech he gave in the British House of Commons. In this speech delivered in 1868, he criticized the land policy of the government in Ireland: "It is, perhaps, too complimentary to call them Utopians, they ought rather to be called dys-topians, or caco-topians. What is commonly called Utopian is something too good to be practicable; but what they appear to favour is too bad to be practicable" (qtd. in Trahair, 1999: 110). However, it is not Stuart Mill who used the word for the first time, but Henry Lewis Younge who used dystopia as a word for the first time as far as is known, which Prof. Sargent, with whom I have exchanged e-mails, explains as:

The first use of this word is usually ascribed to Negley and Patrick's 'Introduction' to their anthology, but there were much earlier uses. Deirdre Ni Chuanacháin has recently noted a 1747 use by Henry Lewis Younge in his Utopia or Apollo's Golden Days (Dublin: Ptd. by George Faulkner) spelled as 'dustopia' used as a clear negative contrast to utopia. Before this discovery, the earliest usage appeared to be in 


\section{Emrah ATASOY}

1782. See Patricia Köster, 'Dystopia: An Eighteenth Century Appearance', Notes \& Queries 228 (n. s. 30, no. 1) (February 1983): 656 , where she says that the first use was in 1782 by Noel Turner (17391826) as dys-topia [first three letters in Greek] in 'Letter VIII' of his Candid Suggestions in Eight Letters to Soame Jenkins, Esq. (London, 1782), 169-72. John Stuart Mill used 'dys-topian' in the House of Common ... According to the OED, Cacotopia was first used by Jeremy Bentham in his Plan of Parliamentary Reform, in the Form of a Catechism (1818, Bowring edition of his Works, 3: 493). ("In Defense of Utopia," 2006: 15)

Dystopian fiction has certain idiosyncratic features, which include fabricated societies, actual, or illusory, unreal settings and imaginary cultural, religious, economic, social and political systems. In these dystopian visions, the ruling body generally has the tendency to be repressive and totalitarian, which helps the dominant power maintain unconditional power. In accordance with this objective, the fictional commanding regime may curb the right to express opinions and viewpoints in a free manner, apply corporal punishment, and implement social stratification in a rigid sense. In this regard, such governing dystopian bodies promote propaganda and demagogy and instill fear in the mind of the citizens of the societies projected.

The way plots of literary dystopias are organized has a huge impact on the practice of power, the fate of the protagonist, the operation of the system and the illustration of hope. The plot of a dystopian text may revolve around an alienated protagonist who might become gradually more and more aware of how the system functions; however, how the protagonist's fate and/or future proceed may differ in each dystopian text. The protagonist may be defeated by the dominant system in some narratives, whereas in some others, s/he may struggle and resist against the coercive body. As to the protagonist's situation, Prof. Moylan enunciates that "the singular misfit finds allies and not only learns the 'truth' of the system" but he also "enters collectively into outright opposition ... Or the outcome may lead to the organization of a resistant enclave, a liberated zone, that sticks in the craw of the hegemonic system; or it may even result in a political movement that threatens to transform the entire order" (2000: xiii).

Experience, which arises in the wake of the geographical and metaphorical journeys of the protagonist, turns out to be the source of why the protagonist physically and psychologically suffers. The newly acquired level of awareness probably results in losses on certain planes for the protagonist, which Erika Gottlieb clarifies as: "The 
protagonist's experience and fate is tragic in the sense that it deals with irrevocable loss on the personal level: he or she loses his position, his beloved, his freedom, and ... his private, individual identity" (2001: 13). However, this article argues that experiential journeys also facilitate the promotion of hope and of the utopian impulse in a seemingly dystopian world order and hint at the potentiality of revised epistemology, which may lead to the formation of a more ideal meritocratic society in critical dystopias, which "prefigure a horizon of hope" (Fortunati, 2013: 35).

Dystopian narrative warns the society against the potential perils of absolute power and of an unbridled rule. In this sense, dystopia expedites critical judgment and satire via its structural and thematic nature. Accordingly, the Italian scholar, Prof. Raffaella Baccolini, and Prof. Moylan speculate about dystopia's capacity and potential for critique pointing out that "the dystopian imagination has served as a prophetic vehicle, the canary in a cage, for writers with an ethical and political concern for warning us of terrible sociopolitical tendencies" (Dark Horizons, 2003: 1-2). Likewise, Judith A. Little elaborates on dystopia as cautionary: "Writers of utopian and dystopian fiction call for social and political action: in utopias, by describing a world in which we want to live, and in dystopias, by warning us of the consequences of current social and political trends" (2007: 14).

Thus, it is not wrong to assert that dystopian fiction highlights a correlation between the fictional world and the real world due to its characteristic as a warning to the society. These literary dystopias cast an insight into the actuality of the real world since they are almost always inspired by the real societies, which become inspirational sources for the production of these texts. In this context, speculative texts can foreshadow potential prospective catastrophes, tyrannies and authoritarianism to be employed and enforced by overbearing regimes. Moreover, dystopian narrative also has the potential to expose how citizens can possibly adhere to submission, subjugation and herd mentality in a fetishistic manner. The regime as the authority does not allow the development of its citizens personally and intellectually; therefore, it poses obstacles to their cultivation. The fictional regime's strict policy on the citizens' progress on certain planes leads potential resisting citizens inevitably to a conflict. Such a suppressive regime has the objective to have an overall manipulation over social life and its numerous aspects through various strategies and means such as propaganda, sexuality, the control of eugenics, 


\section{Emrah ATASOY}

religion, memory, history, gender roles, secret organizations, family, oppression and education.

The journey motif, especially a journey that transforms the main character from a character who may show initial satisfaction or ignorance as to the real nature of the system to a character who speaks his mind and/or sets out to act in an attempt to reverse the dystopian order, gains utmost significance in dystopia. The journey motif projects the fabricated nature of the communicated episteme in dystopia, which M. Keith Booker describes as "a general term encompassing any imaginative view of a society that is oriented toward highlighting in a critical way negative or problematic features of that society's vision of the ideal" (Dystopian Impulse, 1994: 22). This epiphany gives rise to epistemological/epistemic warfare, and arouses and generates the prospect of the utopian hope in dystopias which present "a critique of existing social conditions or political systems ... through the imaginative extension of those conditions and systems into different contexts that more clearly reveal their flaws and contradictions" (Dystopian Literature, Booker, 1994: 3).

The experiential journeys that the protagonist goes through unmask the lacking aspects of utopian aspirations and ideals. The oppressive facet of the system is revealed in the course of these journeys since the protagonist finds himself/herself "bound up in an inescapable web of power relations ... systems of control and surveillance" (Darcy, 2013: 109). A state of maturity ensues in the wake of these journeys. Suffering and pain follow alongside these experiences, yet the openended structure of these novels, namely the ones that do not offer closure, portends optimism and a potentially constructive change in the future. It is through these open-endings that the text suggests "the utopian impulse [to be found] within the work" ("Gender and Genre," Baccolini, 2000: 18).

A brief theoretical perspective will contribute to the argument of this article, which seeks to reveal the utopian impulse in dystopian narrative, with a special focus on critical dystopias in the light of the protagonist's experiential journeys in P. D. James's critical dystopia, The Children of Men (1992). Theoretical sources such as the French philosopher, Michel Foucault's critical stance towards knowledge, power, discourse, and surveillance society and Thomas Robert Malthus's understanding of population are crucial in this article's endeavor to uncloak the possibility of hope in dystopian narrative.

To start with, population control is deemed as one of the principal characteristics of dystopian powers, which is exemplified in 
numerous literary dystopias. The writers of speculative fiction may come up with a society, which may suffer from overpopulation or depopulation. The way such a society is designed in terms of the amount of population thus plays an instrumental role in how the ruling power organizes and regulates social life and social stratification. The attempt to find an answer to the question, "[w] hat is the link between population and governance in the overpopulated [or depopulated] societies of these dystopias, whether in the megalopolises or in the superpower blocs of the imagined world?" clarifies the functional role of population in dystopian narrative (Domingo, 2008: 730). Malthus's work on demography and population, An Essay on the Principle of Population (1798) calls attention to the threat of overpopulation and how nature would react to such a population that is constantly growing. Malthus asserts that population growth should be checked by societies on a regular basis. When a society fails to check it, which then progresses unchecked, there is ultimately no possibility for nature to provide sufficient subsistence.

Population, which is unchecked, results in the necessity to lower the living standards. Therefore, escalation in population and the capacity to provide subsistence should be balanced. According to Malthus, nature through natural catastrophes like earthquakes and famine and/or some other external factors such as wars, pestilence intervene in case of overpopulation:

... the introduction or failure of certain manufactures, a greater or less prevalent spirit of agricultural enterprise, years of plenty, or years of scarcity, wars and pestilence, poor laws, the invention of processes for shortening labour without the proportional extension of the market for the commodity, and, particularly, the difference between the nominal and real price of labour, a circumstance which has perhaps more than any other contributed to conceal this oscillation from common view. (1798: 10)

Hence, a society, which suffers from overpopulation is unable to supply adequate subsistence since "the power of population is indefinitely greater than the power in the earth to produce subsistence for man" (Malthus, 1798: 4). A Malthusian viewpoint on population plays a vital inspirational role in dystopian narrative, which is also exemplified in James's literary dystopia as literary dystopias are influenced by the drastic changes in population in the twentieth century. 


\section{Emrah ATASOY}

The link between power, knowledge and discourse is also significant in dystopian narrative. Power occupies a position, which is indispensable in dystopian narrative since power relations are what shapes and regulates social life, the society and knowledge. The ideological discourse imposed by the ruling power is influenced by the manipulation and distortion of episteme in order to maintain an overall control over the society. In this regard, Foucault's concept of power is conducive to comprehend how the system uses and abuses knowledge and power in order to forge a certain ideological mindset. Power relations have a direct impact over discursive practices because they are "not purely and simply modes of manufacture of discourse. They take shape in technical ensembles, in institutions, in behavioral schemes, in types of transmission and dissemination, in pedagogical forms that both impose and maintain them" (Ethics, Foucault, 1997: 12). The ruling power may create and enforce a specific kind of discourse based on a certain ideology in order to reinforce its position. Generation of such a discourse has an inseparable relation to and coexistence of power and truth.

The social body is created through power relations, which circulate and which cannot be thought of without discourses of truth in a Foucauldian sense. In dystopian fiction, Foucault's outlook on power's multi-layered structure becomes significant thereof:

-Power is not something that is acquired, seized, or shared ... power is exercised from innumerable points, in the interplay of nonegalitarian and mobile relations.

-Power comes from below; that is, there is no binary and allencompassing opposition between rulers and ruled at the root of power relations, and serving as a general matrix.

-Power relations are both intentional and nonsubjective. (History of Sexuality, 1978: 94)

Social and collective level is therefore where power functions on an effective level, shaping the shared mainstream knowledge and/as truth. Citizens are supplied with a certain type of episteme in order to continue with their lives. Some characters, however, generally the protagonist find himself or herself in a situation, in which s/he questions the soundness and trustworthiness of such implanted episteme. This questioning of power relations takes place under the strong influence of some external elements such as a stranger, a beloved person, or a shift in power exercise within the boundaries of the social order. 
People are born into a kind of discourse on truth and power structure, which have a mutual, reciprocal relation. This relationship becomes crucial in formulating an ideology and maintaining a lifestyle accordingly (Society, Foucault, 2003: 29). This indispensable correlation between power and discourse enables transformation of the actual meaning of episteme into another type of episteme, which becomes distorted. The new shape of the recently generated knowledge is then turned into the broadly recognized and accepted truth for the general public in the society. Knowledge is subsequently molded since "a discursive tactic, a deployment of knowledge and power which ... is transferable and eventually becomes the law governing the formation of a knowledge and, at the same time, the general form of the political battle" (Society, 2003: 190).

Resistance follows as a result of epistemic manipulation, frustration and discontent. It comes into question when power is to be used and exploited in such a manner that it fails to reach an overall contentment, becoming repressive and restraining. It is through the practice of power in a deliberate manner that the regime in a literary dystopia strives to scheme its own utopian order. However, one regime's utopia may then turn into some citizens' dystopia in such fictional literary representations. Resentment ensues among the frustrated individuals, who feel left out and/or suppressed by the state. Power and resistance, for Foucault, thus co-exist, that is to say, resistance is immensely probably in multiple forms as either target or support wherever power exists (History of Sexuality, 1978: 95). Thus, resistance, which is closely linked with power, is seen in numerous forms in dystopia: "[R]esistances that are possible, necessary, improbable; others that are spontaneous, savage, solitary, concerted, rampant, or violent; still others that are quick to compromise, interested, or sacrificial" (History of Sexuality, Foucault, 1978: 96).

These resistances become essential and influential in criticizing the lacking aspects of the extant order juxtaposed with the vital role of power relations. It is the active role of power, which fashions the rhetoric on episteme, regulating life on different social planes. This in return leads some citizens, especially the main character to resist as power is "necessarily resisted because it is necessarily constraining ... resisted not by a force external to it, but precisely at the point of its application" (May, 1993: 114). As a result, in some dystopian projections, the protagonist in such an epistemological warfare may be either suppressed, crushed, remolded or exterminated owing to defying against the power 


\section{Emrah ATASOY}

implementation of the ruling body. This may imply a seeming loss of hope in a dystopian world, in which hope may not find a fruitful platform to blossom. In such an ambiance, s/he may be deprived of a free territory from the repressive strictures of the system. In some other dystopian illustrations, the protagonist may not be destroyed or killed. In this case, his or her survival and the open-ended structure of the literary work can augur well for a potential change and the probability of the utopian impulse in a dystopian envision of a social order in twentieth century dystopian fiction, particularly critical dystopias. At this point, it is important to briefly explain the concept of critical dystopia prior to the analysis of James's novel.

\section{Critical Dystopia}

Dystopian narrative went through various fluctuations in the twentieth century indicating differing tendencies. Dystopian tendency reemerged in the 1980s and 1990s, however, literary dystopias in these decades do not portray a dystopian representation like classical dystopias, which offer closure lacking in any room for flexibility. It is possible to find the utopian impulse and hope in these critical dystopias through the open-ended structure, which can bring alternative possibilities in the face of the extant order to mind. This term can be drawn upon to spotlight the paradigm shift in dystopian narrative and to highlight the utopian enclave in the twentieth century dystopian fiction, particularly in James's vision.

Critical dystopia as a term accentuates the residual hope in dystopia, which is generally referred to as pessimistic, denying the possibility of hope in its nature. Prof. Sargent describes this term as:

A non-existent society described in considerable detail and normally located in time and space that the author intended a contemporaneous reader to view as worse than contemporary society but that normally includes at least one eutopian enclave or holds out hope that the dystopia can be overcome and be replaced with a eutopia. ("US Eutopias," 2001: 222)

That at least one eutopian enclave in Sargent's terms gains immense significance in the discussion of critical dystopias. Transformative journeys of the protagonist facilitate deconstructing the firmly established norms, and ends in epistemic warfare between the audacious protagonist and the dominant power. To this end, critical dystopia "opens a space of contestation and opposition for those groups (women and other 'eccentric' subjects whose subject position hegemonic discourse does not contemplate) for whom subjectivity has 
yet to be attained" (Baccolini, "Gender and Genre," 18). Baccolini further argues that critical dystopias through their "permeable borders, questioning of generic conventions, and resistance to closure" emerge as one of the "preferred sites of resistance" since they include "empowerment, resistance, utopian imagination, and awareness" (“Gender and Genre," 2000: 30).

Critical dystopia makes it possible to trace the utopian enclave in the literary dystopias even within the text itself: "[D]ystopias maintain utopian hope outside their pages, if at all ... the new critical dystopias allow both readers and protagonists to hope by resisting closure: the ambiguous, open endings of these novels maintain the utopian impulse within the work" (Dark Horizons, Baccolini and Moylan, 2003: 7). Critical dystopias do not only serve as cautionary tales, but they do take an active position in the potentiality of substantial transformation. These literary texts withstand "hegemonic and oppositional orthodoxies" and "begin to find ways to transform it that go beyond the limitations of both the radical micropolitics and the compromised centrist 'solutions' of the 1990s" (Moylan, 2000: 190). This confrontational resistance, for Moylan, makes it possible "to develop the critical capacity of people to know, challenge, and change those aspects of it that deny or inhibit the further emancipation of humanity" (2000: 199). The following part of the article is dedicated to the discussion and analysis of P. D. James's novel, The Children of $M e n^{5}$ as an example of critical dystopia in an attempt to reveal the utopian impulse and hope in twentieth century dystopian narrative.

\section{In Search of Hope and Utopian Impulse in The Children of Men by P. D. James}

The Children of Men (1992), has not achieved critical and scholarly acclaim it deserves, probably due to the success of the famous film director, Alfonso Cuaron's film, Children of Men (2006). Brief information about Phyllis Dorothy James White, Baroness of James of Holland Park, known as P. D. James's style is crucial in promoting her work and comprehending the textual discussion and the socio-political background prior to the analysis of the text. James was endowed with the title, Queen of Crime as a mystery and detective

\footnotetext{
${ }^{5}$ James's novel has not been referred to as "a critical dystopia" yet; however, I find it useful to label this novel as an example of critical dystopia due to the time span in which it was written and particularly the eutopian enclave / the utopian impulse and hope it has/offers, which forms the main argument of this article.
} 


\section{Emrah ATASOY}

fiction novelist. Her novels have been televised and adapted to the screen. Her first novel, Cover My Face (1962) introduced the character of Adam Dalgliesh, initially a police inspector in Scotland Yard and a detective. Her work highlights Dalgliesh, "an intelligent, sensitive widower who is a published poet in addition to his profession as a homicide investigator" (Lindsay, 2007: 122).

James, who is acknowledged as one of the most important writers of the twentieth century, has an idiosyncratic style as a writer. Her novels have "a puzzle plot and genteel characters ... her characters are more fully realized, and she delves into their emotions and motivations in a way that was uncommon for earlier crime novelists" (Haynes, 2011: 79). She has "deftness in creating plot, setting and character ... [and] her demonstration of moral sensitivity and humanistic concerns." (Joyner, 1981: 22). There are many interviews with P. D. James, which look for information about her crime and detective fiction because she is often deemed as the successor to Agatha Christie, Margery Allingham and Dorothy L. Sayers. However, academic insight into her contribution to dystopian narrative, namely her only dystopian text, The Children of Men (1992) is still lacking. Alfonso Cuaron's 2006 film, Children of Men, based on James's novel, has brought the book to light and provided more inter/national recognition. Nevertheless, the film seems to have accomplished more prominence and critical acclaim compared to the book. This article therefore hopes to contribute to the utopian studies and dystopian literature by attempting to partially fill the gap in the discussion of James's alternative vision with a special focus on the possibility of yet another utopian hope in the aftermath of such a nightmarish dystopian social vision.

The Children of Men is divided into two parts: Omega (JanuaryMarch 2021) and Alpha (October 2021). It illustrates a future England set in 2021, in which the world is stricken with sterility, mass infertility, and impotence. The world faces the risk of depopulation and puts the future of humanity in jeopardy. Males cannot produce offspring. The world is taken to despair and anguish after the death of Joseph Ricardo, the last human being to be born on earth in Buenos Aires. Countries collaborate and conduct scientific research in order to find a solution to this global disaster. Xan Lyppiatt, the Warden of England, promises to terminate the epidemic of infertility, but fails to do so. Lyppiatt's rule brings forward other alternatives instead: promoting voluntary self-killing, that is implementing Quietus; the semen-testing programme; compulsory gynaecological examinations 
and the routine examination of women; opening State porn shops; the establishment of the Man Penal Colony; and importing the Sojourners / the Omegas from other less prosperous countries to do unpleasant work once those individuals reach the age of sixty. The members of the group called the Five Fishes are not content with these practices and resistance ensues in the aftermath of disgruntlement. The protagonist, Theodore Faron finds himself unexpectedly in the group's resistance under the influence of his passionate feelings for one of the group members, Julian, who is revealed to be pregnant, probably the only pregnant woman in the world as far as is known. Ultimately, the baby is born and the Warden is killed by Theodore. The book ends with the christening of the baby.

The developments of her time gave James inspiration for this thought experiment. She was affected by the population decline in Europe, particularly in England during the 1980s and the 1990s. The statistical estimates of the future of population (a gradual decline in the number of children to be born) and the aging population contributed to James as an inspiration source "As early as 1991 a European Community Report showed a slump in the number of children born in Europe---8.2 million in 1990, with particular drop in the Roman Catholic countries" (James, 1992: 8). James expresses how actual events influenced the novel:

This novel, which is totally different from all my other work, didn't begin with a setting, but with a review I read in the Sunday Times. The book reviewed dealt with the dramatic and so far unexplained fall in the fertility rate of Western man... I began to imagine what the world would be like, and more specifically what England would be like, a quarter of a century after a catastrophic year in which the human race was struck by a universal infertility. (qtd. in Young, 2017: 57)

This factual inspiration also played a role in her preference for the title, which is closely linked with the theme; therefore, her choice for the title of the book needs to be explicated. She chooses intentionally to make use of the word "men" rather than "humanity, humankind" so as to demonstrate to whom the children in this world belong. Her title in a way excludes women and places an emphasis upon the male. Its implication of children as belonging to men hints at the suppression of the female voice in spite of the fact that her narrative reflects the viewpoint of the female characters substantially. The male characters dominate the narrative although the males, except for Luke, a priest and the unborn baby's father, are infertile. The protagonist, Theo and 


\section{Emrah ATASOY}

the Warden of England, who is furnished with authority to govern the country, are male. Moreover, the title implies a patriarchal rule both extolling men and imposing an enormous burden on them.

In addition to these possible explanations, there is a further religious connotation since James uses the Bible as an inspirational source for her book: "You turn man to destruction; and say, Return, you children of men" (The Holy Bible, "The Eternity of God, and Man's Frailty," 2004: Psalm 90). She directly quotes from the Bible, which Theo articulates during the Burial Service for Luke:

Lord, thou hast been our refuge: from one generation to another. Before the mountains were brought forth, or ever the earth and the world were made: thou art God from everlasting, and world without end. Thou turnest man to destruction: again thou sayest, Come again, ye children of men. For a thousand years in thy sight are but as yesterday: seeing that is past as a watch in the night. (James, 1992: 194)

This quotation, which draws attention to the omnipotent power of God as both benevolent and retributory, is a prayer of Moses. Rick Schramm interprets the word, men as adam, which refers to "those who believed the lies of the Serpent, who is Satan ... So the verse 'Return, $\mathrm{O}$ children of men' means something like 'Return, $\mathrm{O}$ children of Adam' or 'Return, 0 fallen children of Satan who formerly dwelled as my children!'” (2014: 202). This interpretation is instrumental in that it reflects the dystopian aura of the extant socio-political order since it correlates humans with Satan and Adam, the tempter and the tempted respectively. Furthermore, it implies the possibility of the ultimate utopian impulse, which engenders revisionary epistemology in the aftermath of Theo's transformative journey due to its implied belief in divine power.

Theo continues the Burial Service with the lines from the Book of Common Prayer (1662): "Earth to earth, ashes to ashes, dust to dust; in sure and certain hope of the Resurrection to eternal life, through our Lord Jesus Christ" (James, 1992: 194). These lines, which refer to the resurrection of Jesus Christ, are spoken by the priest "as the corpse is lowered into the grave" (McGrath, 2015: 224). Hope stands out as the main feature of the burial service, especially influenced by the hope of resurrection. To conclude, James's title choice is not coincidental but efficient because what it connotes illustrates the controversial nature of the extant political order extrapolated, creating an aura of pessimism. It also presents an epistemological 
warfare between the political body and the protagonist, resulting in the ruler's eventual death, which in a way subverts the system.

Xan's regime desires to exercise extreme power in order to serve the collective or individual desires of certain groups or figures. Power exercise as a triggering force portrays the political dynamics of Xan's order, which highlights the growing hankering for more clout. It is what shapes the projected episteme and numerous aspects of the social sphere. Power is referred to as more in terms of power to reproduce, to give birth at the beginning of the novel: "Overnight, it seemed, that the human race had lost its power to breed" (James, 1992: 8). However, this usage later on takes on a sense of political power. Xan's political power in this regard leads to both collective submissive conformity and rebellious opposition by seditious individuals. On the surface, it seems to facilitate an atmosphere of resignation, appeasement and allegiance. In a world stricken with global infertility, the majority of the citizens are made to adopt the desperate preventative precautions in the aftermath of the actions of Xan's powerful regime.

James's depiction of power does not prioritize one group/individual over another since she directs attention to desire for power and the ensuing addiction to extreme power and authority practice, which results in corruption and manipulative discourse. Xan's remarks about power towards the very end of the novel in the aftermath of the revelation of Julian's pregnancy clarifies the paramount significance of power: "Good God, Theo, do you realize what power is in our hands? Come back on the Council, be my lieutenant. You can have anything you want" (James, 1992: 237). Xan's words on the potential function of power accentuates his aspiration and longing to mold episteme and truth presented to the citizens in order to maintain thorough control over the society. The party that enjoys political power in a similar vein thus enjoys the power to engineer the social values and norms in such a way that it does not welcome the plurality of voices and diversity of opinions; rather, it welcomes and embraces an aura of monomania, which offers indifference, lethargy, and apathy. The political discourse created therefore plays an instrumental role in establishing the normative beliefs, attitudes, social norms and truth in Xan's authoritarian despotic regime through the functioning of power relations.

The lust for power becomes clear not only on the level of the political figure, the Warden of England, but to the degree of some other individual characters in the novel. In this regard, it is a driving force 


\section{Emrah ATASOY}

for some characters like Rolf to take a step to revolt against the government. Rolf, Julian's husband and the alleged leader of the Five Fishes, the defiant rebellious group, does not act on the mere grounds of bringing yet another more ideal social order. Rather, he acts intuitively to acquire power and to introduce his own political system. His emphasis of his position in the group illustrates his growing thirst for absolute power: "There's no need for you to know our surnames. We'll use forenames only. I' am Rolf and I'm the leader of the group" (James, 1992: 54-55). James's depiction of his physical appearance also differentiates him from the other members of the group since he is depicted as having a dark masculinity. His curiosity about Xan's extreme power foreshadows his own obsession with power: "All that power, more than anyone has ever had before----in this country anyway----all in his hands. Does he enjoy it? ...The Warden controls the system from top to bottom, you must know that" (James, 1992: 59).

The novel's narrative attaches importance to transformation, including that of the dystopian protagonist. Towards the end of the novel, the dystopian ambiance in the forest gives way to a utopian aura before the birth when Theo, Miriam, and Julian find a wood-shed to deliver the baby: "[T] he forest was transformed from a place of darkness and menace ... into a sanctuary, mysterious and beautiful" (James, 1992: 222). Among the peaceful, tranquil atmosphere of the forest, nature as refuge makes Theo understand why Julian insisted on giving birth without Xan's presence: "For her Xan was evil. The word has a meaning for her ... He could understand now her obstinate choice and it seemed to him, sitting in this peace and quietness, to be both right and reasonable" (James, 1992: 225). With the help of Miriam, Julian gives birth a son in such a wood-shed, which can be compared with Jesus Christ's alleged birth in the barn.

The last section of the book, in which Theo confronts and kills Xan, highlights his transition into a new state of knowledge and the possibility of the utopian impulse out of such a dystopian order. Theo's conversation with Xan in the last section represents Xan's real motive, which is to gain even more power. Xan, who has an ambulance, doctors, helicopters, and midwives with him, goes alone to witness the pregnant mother, unaware of the fact that she has already given birth. However, Theo meets him. Xan tells Theo that Gascoigne, Rolf, and Miriam (garroted, strangled to death) have been killed, and that he is planning to produce fertile sperm from the baby at the age of twelve or thirteen, and marry Julian. Xan as a dystopian ruler is interested solely in the power he will attain through this baby: "Theo, do you 
realize what power is in our hands?" (James, 1992: 237). Theo's grasp of Xan's true despotic motives and his pejorative remarks about Julian lead Theo to shoot Xan through the heart with the gun he acquired from Jasper's house.

Theo manages to get the Coronation Ring (the ring that gives Xan power) from Xan's finger, and tells Carl Inglebach, Martin Woolvington, the two women, and six Grenadiers that the Warden is dead. Attaining the ring becomes pivotal as an act, "instinctive and yet deliberate, a gesture to assert authority and ensure protection" (James, 1992: 240). He decides to take Xan's place for some time in order to do away with the despotic impositions of the regime: "There were evils to be remedied; but they must take their turn. He couldn't do everything at once, there had to be priorities ... It's useful for the present. I shall take it off in time" (James, 1992: 241). In the end, Xan dies; Theo gets the Coronation Ring in order to deal with the extant problematic issues; and Theo christens the baby and gives him the name "Luke Theodore / Theodore Luke." The novel thus ends on a very Christian tone.

However, before discussing the possible ramifications of Theo's transformative journey, and its relation to the hope for a new revisionary epistemology, it is useful to briefly touch upon the significance and symbolic meaning of the baby within the context of the projected world. In a world of global infertility, the baby represents the seed of a new hope: the world will be able to repopulate if he has the fertile sperm. He is regarded as a miracle that will save the world from despair, thereby symbolizing hope for the world. The dystopian world order is subverted and dystopian social engineering fails to manipulate society. Accordingly, the possibility of a revisionary epistemology and the utopian impulse are born with the birth of the baby. Moreover, Julian's birth and the baby himself contribute to the plot development by heightening suspense and contributing to characterization.

The significance of the baby reverberates throughout the narrative by mirroring the excessive and obsessive desires of some characters such as Xan and Rolf, who yearn to exploit the baby to obtain more power or to consolidate extant power. These characters have an infatuation and preoccupation with absolute power; therefore, the baby becomes an important tool that they want to use to buttress their authority and to have enough power to fashion the world according to their wills. Their interest does not lie in the baby or the welfare of the people, but in the benefit they will derive from 


\section{Emrah ATASOY}

the baby as they only care about their individual, egoistical and pragmatic interests. Finally, the baby can be also interpreted in a religious light. The baby is born in a wood-shed, which can be correlated with Jesus Crist's birth. He becomes the hope of the world to come, in a way as the new savior of the world; similarly, Jesus Christ represents hope for humanity and serves as the savior who according to Christian theology, sacrificed himself and was crucified for the sins of humans. At the end of the novel, the baby is christened and baptized by Theo: "It was with a thumb wet with his own tears and stained with her blood that he made on the child's forehead the sign of the cross" (James, 1992: 241). Julian is a devout Christian, and believes in the omnipotent power of God, which informs the Christian undertone. In this regard, James probably communicates her wish for the formation of a more religious, Christian society through the baptism of the baby, who is to father the new race and the new world.

To conclude, Theo's transformative journey transforms him from a citizen, who is initially ignorant and apathetic towards the dystopian impositions of Xan's despotic regime to a citizen, who gains critical awareness into the reality of the political system constructed around him; this all takes place under the strong influence of an external agent, the female character, Julian. He goes through difficulties and mishaps throughout the narrative such as his ruined marriage, the accidental manslaughter of his daughter, the violent confrontation with the Painted Faces, the discovery of the suicide of his friend, the death of an elderly woman, and ultimately the murder of the Warden of England. All of these experiences, though negative, help him transition to a state of maturity and of knowledge in such a dystopian social order. His attraction to Julian maintains his share in the cause of the subversive group, the Five Fishes, and contributes to his critical insight into the dystopian mechanics of the extant order, which draws on manipulative social engineering and authoritative rhetoric through the alleged provision of comfort, security, and pleasure.

It becomes increasingly clear to Theo that Xan's rule aims to create a collective society consisting of members who have total conformity to the normative ethics and values of the hegemonic power. His rule does not tolerate diversity, plurality of ideas, multiplicity of perspectives, or individualism. Dissident citizens who have an oppositional stance therefore become the target of the regime. Xan's pragmatic and egoistical interests pervade James's narrative. The regime has constructed an inegalitarian and unmeritocratic 
dystopian social order through distortion, fabrication, falsification, misstatement, manipulation, inhumane treatment of the immigrants, the Sojourners, promotion of Quietus, deportation of criminals to the hellish Isle of Man, and compulsory semen testing against people's wills. All these despotic practices result in the subversive act of creating the Five Fishes and lead them to resist against the regime. Theo finds himself involved in their resistance movement and the ensuing warfare, which brings about the possibility of a revisionary epistemology.

In the end, Theo's naïve innocence or ignorant state is shattered in the wake of his metaphorical journey. This transition from innocence to experience turns him into an outcast as he is pushed into a clash with the ruling body. His exile, however, cannot prevent him from revealing the truth about the regime that is unable to exterminate him. His murder of Xan may imply the death of the extant nightmarish order and the possibility of a new utopian order, which could welcome diversity and plurality of viewpoints. His survival attests to the failure of Xan's totalitarian regime. Furthermore, the open-ended narrative of James's dystopian novel hints at the hope of a revisionary knowledge that might lead to a better, more just society.

\section{Conclusion}

Dystopian fiction in the twentieth century should not be viewed as totally pessimistic in the light of the discussion. This article has demonstrated and discussed the possibility of the utopian enclave and hope to be ascertained and resurfaced in the light of the protagonist's transformative journeys, particularly in critical dystopias. The open-ended structure of these literary dystopias, the protagonists' survival in the face of the repressive body in an epistemic warfare, and/or communication of the secrets of the operation of the system facilitate and engender yet another potential utopian impulse in a dystopian social order. The transformative journey of the dystopian protagonist awakens the protagonist to the reality of the despotic regime, thereby facilitating the transition from innocence and ignorance to a new state of knowledge and experience. The protagonist's victory in epistemological warfare against the ruling power helps provide the undistorted truth in the aftermath of the regime's failure. This increases the potential for hope in the quest for the utopian impulse and the possibility of a body of revisionary epistemology that might facilitate the formation of a new more ideal meritocratic egalitarian society. 


\section{Works Cited}

Baccolini, Raffaella and Tom Moylan (2003), Introduction. Dark Horizons: Science Fiction and the Dystopian Imagination. Eds. Raffaella Baccolini and Tom Moylan. New York \& London: Routledge, p. 1-12.

--- (2000), "Gender and Genre in the Feminist Critical Dystopias of Katharine Burdekin, Margaret Atwood, and Octavia Butler." Ed. Marleen S. Barr. Future Females, The Next Generation: New Voices and Velocities in Feminist Science Fiction Criticism. Lanham: Rowman \& Littlefield, p. 13-34.

Bammer, Angelika (1991), Partial Visions: Feminism and Utopianism in the 1970s. New York \& London: Routledge.

Booker, M. Keith (1994), Dystopian Literature: A Theory and Research Guide. Westport, CT: Greenwood.

--- (1994), The Dystopian Impulse in Modern Literature: Fiction as Social Criticism. Westport, CT: Greenwood.

Darcy, Soo (2013), "Power, Surveillance and Reproductive Technology in P. D. James' The Children of Men." Women's Utopian and Dystopian Fiction. Ed. Sharon R. Wilson. Newcastle upon Tyne: Cambridge Scholars Publishing, p. 88-111.

Domingo, Andreu (2008), “Demodystopias': Prospects of Demographic Hell." Population and Development Review 34.4, p. 725-745.

Foucault, Michel (2003), Society Must Be Defended: Lectures at the Collége De France, 1975-76. Trans. David Macey. Eds. François Ewald and Alessandro Fontana. New York: Picador.

--- (1978), The History of Sexuality: An Introduction. Vol. 1. Trans. Robert Hurley. New York: Vintage Books.

--- (1997), Ethics: Subjectivity and Truth. Trans. Robert Hurley and Others. Ed. Paul Rabinow. New York: The New Press.

Fortunati, Vita (2013), "Why Dystopia Matters." Dystopia(n) Matters: On the Page, on Screen, on Stage. Ed. Fatima Vieira. Newcastle Upon Tyne: Cambridge Scholars Publishing, p. 28-36.

Gottlieb, Erika (2001), Dystopian Fiction East and West: University of Terror and Trial. Montreal: McGill-Queen's UP.

Haynes, Elizabeth (2011), Crime Writers: A Research Guide. Santa Barbara, California: Libraries Unlimited.

James, P.D (1992), The Children of Men. New York: Vintage Books. 
Joyner, Nancy Carol (1981), “P. D. James.” 10 Women of Mystery. Ed. Earl F. Bargainnier. Bowling Green: Bowling Green State UP, p. $107-23$.

Levitas, Ruth (1990), The Concept of Utopia. Syracuse, N.Y.: Syracuse UP.

Lindsay, Elizabeth Blakesley (2007), Great Women Mystery Writers. 2nd ed. Westport, Connecticut: Greenwood Press.

Little, Judith A (2007), Introduction. Feminist Philosophy and Science Fiction: Utopias and Dystopias. Ed. Judith A. Little. New York: Prometheus Books.

Malthus, Thomas (1798), An Essay on the Principle of Population. London: Printed for J. Johnson, in St. Paul's Church-Yard.

May, Todd (1993), Between Genealogy and Epistemology: Psychology, Politics, and Knowledge in the Thought of Michel Foucault. University Park, Pa: Pennsylvania State UP.

Moylan, Tom (2000), Preface. Scraps of the Untainted Sky: Science Fiction, Utopia, Dystopia. Colorado: Westview Press.

McGrath, Alister E (2015), Christianity: An Introduction. $3^{\text {rd }}$ ed. West Sussex: WILEY Blackwell.

Sargent, Lyman Tower (1994), "The Three Faces of Utopianism Revisited." Utopian Studies 5.1, p. 1-37.

--- (2006), “In Defense of Utopia” Diogenes 53.11, p. 1-17.

--- (2001), "US Eutopias in the 1980s and 1990s: Self-Fashioning in a World of Multiple Identities." Utopianism/Literary Utopias and National Cultural Identities: A Comparative Perspective. Ed. Paola Spinozzi. Bologna: COTEPRA/ University of Bologna, p. 221-32.

Schramm, Rick (2014), Seeing the Forest despite the Tree: The Meaning and Purpose of Life on Earth. Bloomington, In: WestBow Press.

The Holy Bible (2004), The Essential Evangelical Parallel Bible: New King James Version, English Standard Version, New Living Translation, the Message. Ed. John R. Kohlenberger. Oxford: Oxford UP.

Trahair, R. C. S (1999), Utopias and Utopians: An Historical Dictionary. Westport, Conn: Greenwoord Press.

Young, Laurel A (2017), P. D. James: A Companion to Mystery Fiction. Ed. Elizabeth Foxwell. Jefferson, NC: McFarland. 
264 | Celal Bayar Üniversitesi Sosyal Bilimler Dergisi - Cilt: 17, Sayı: 1, Mart 2019 